\title{
HUBUNGAN PELAYANAN ANTENATAL CARE (ANC) TERPADU DENGAN PEMERIKSAAN PENCEGAHAN PENULARAN DARI IBU KE ANAK (PPIA) DI PUSKESMAS SLEMAN
}

\author{
THE RELATIONSHIP OF ANTENATAL CARE (ANC) SERVICES \\ INTEGRATED WITH SPREAD OF CHILDREN (PPIA) PREVENTION \\ EXAMINATION IN SLEMAN HEALTH CENTER
}

\author{
Suci Musvita Ayu, Ana Amalia Rizqi \\ Fakultas Kesehatan Masyarakat, Universitas Ahman \\ Dahlan,
}

\begin{abstract}
Maternal Mortality rate (MMR) in Sleman Regency in 2017 was 42.78 per 100,000 live births, MMR decreased compared to 2016 which was 56.59 per 100,000 live births. While the Infant Mortality Rate (IMR) was 4.20 per 1,000 live births, IMR increased compared to 2016 at 3.11 per 1,000 live births. Efforts to reduce maternal and infant mortality are through integrated antenatal care services. The purpose of this study was to determine the relationship between integrated antenatal care (ANC) services and maternal-child transmission prevention (PMCT) in Pregnant Mothers in Puskesmas Sleman. The study design was analytic observational with cross-sectional design. Research subjects were Pregnant Mothers in Puskesmas Sleman. The research sample was 104 people with purposive sampling technique. This research tool is a questionnaire. Data analysis was univariate and bivariate. Significant value of 0.001 (p $<0.05$ ) can be seen that there was a relationship between integrated Antenatal Care (ANC) services and examination of maternal-child Transmission Prevention (PMCT) in Pregnant Mothers in Puskesmas Sleman 2018, the value of Prevalence Risk is 25,714 (> 1) and CI value is in range of 3,094 and 213,742, so that it does not pass through the number one, meaning that the variable is a risk factor. There was a relationship between integrated antenatal care (ANC) services with maternal-child transmission prevention (PMCT) on the Pregnant Mothers in Puskesmas Sleman.
\end{abstract}

Keywords: ANC services, PPIA examination, pregnant mother

\begin{abstract}
ABSTRAK
Angka kematian ibu (AKI) di Kabupaten Sleman pada tahun 2017 adalah 42,78 per 100.000 kelahiran hidup, AKI menurun dibandingkan 2016 yang sebesar 56,59 per 100.000 kelahiran hidup. Sementara Angka Kematian Bayi (AKB) adalah 4,20 per 1.000 kelahiran hidup, AKB meningkat dibandingkan dengan 2016 sebesar 3,11 per 1.000 kelahiran hidup. Upaya untuk mengurangi angka kematian ibu dan bayi adalah melalui layanan perawatan antenatal terintegrasi. Tujuan dari penelitian ini adalah untuk mengetahui hubungan antara layanan perawatan antenatal terintegrasi (ANC) dan pencegahan penularan ibu-anak (PMCT) pada Ibu Hamil di Puskesmas Sleman. Desain penelitian adalah observasional analitik dengan desain cross-sectional. Subjek penelitian adalah Ibu Hamil di Puskesmas Sleman. Sampel penelitian adalah 104 orang dengan teknik purposive sampling. Alat penelitian ini adalah kuesioner. Analisis data adalah univariat dan bivariat. Nilai signifikan 0,001 ( p <0,05) dapat dilihat bahwa ada hubungan antara layanan Antenatal Care (ANC) terintegrasi dan pemeriksaan Pencegahan Penularan Ibuanak (PMCT) pada Ibu Hamil di Puskesmas Sleman 2018, nilai Risiko Prevalensi adalah 25.714 (> 1) dan nilai CI berada di kisaran 3.094 dan 213.742, sehingga tidak melewati angka satu, artinya variabel tersebut merupakan faktor risiko. Ada hubungan antara layanan perawatan antenatal terpadu (ANC) dengan pencegahan penularan ibu-anak (PMCT) pada Ibu Hamil di Puskesmas Sleman
\end{abstract}

Kata kunci: Layanan ANC, pemeriksaan PPIA, ibu hamil 


\section{PENDAHULUAN}

Situasi derajat kesehatan di suatu wilayah digambarkan dalam berbagai indikator yang paling peka dan telah disepakati secara nasional sebagai ukuran derajat kesehatan suatu wilayah. Angka Kematian Ibu (AKI), Angka Kematian Neonatus (AKN), Angka Kematian Bayi (AKB) dan Angka Kematian Balita (AKABA) merupakan indikator status kesehatan masyarakat. Dewasa ini AKI dan AKB di Indonesia masih tinggi dibandingkan dengan negara ASEAN lainnya. Berdasarkan Survei Demografi dan Kesehatan Indonesia pada tahun 2012, AKI diperkirakan mencapai 359 kematian maternal per 100.000 kelahiran hidup, AKB menurut SDKI tahun 2012 terdapat 32 kematian per 1000 kelahiran, AKN 19 per 1.000 kelahiran hidup, AKABA 44 per 1000 kelahiran hidup (Dinkes DIY, 2017).

Faktor yang berkontribusi terhadap kematian ibu, secara garis besar dapat dikelompokkan menjadi penyebab langsung dan penyebab tidak langsung. Penyebab langsung kematian ibu adalah faktor yang berhubungan dengan komplikasi kehamilan, persalinan dan nifas seperti perdarahan, preeklamsia/eklampsia, infeksi, persalinan macet dan abortus. Penyebab tidak langsung kematian ibu adalah faktor-faktor yang memperberat keadaan ibu hamil seperti empat terlalu (terlalu muda, terlalu tua, terlalu sering melahirkan dan terlalu dekat jarak kelahiran) dan tiga terlambat (terlambat mengenali tanda bahaya dan mengambil keputusan, terlambat mencapai fasilitas kesehatan dan terlambat dalam penanganan kegawatdaruratan). Faktor lain yang berpengaruh adalah ibu hamil yang menderita penyakit menular seperti malaria, Human Immunodeficiency Virus (HIV) / Acquired Immunodeficiency Syndrom (AIDS), tuberkulosis (TB), sifilis, penyakit tidak menular seperti hipertensi, diabetes mellitus, jantung, gangguan jiwa maupun yang mengalami kekurangan gizi (Kemenkes RI, 2010). Wanita hamil yang tidak melakukan perawatan kehamilan mempunyai risiko terjadinya abnormal 1,6 kali lebih tinggi dibanding wanita yang melakukan pemeriksaan kehamilan (Andriani, 2009). Penelitian Ariningtyas (2017) menyatakan bahwa pelaksanaan PPIA pada pelayanan kesehatan ibu dan anak dapat menurunkan angka kematian pada ibu HIV. 
Pelayanan Bidan Praktik Mandiri merupakan salah satu fasilitas pelayanan kesehatan ibu dan anak yang ada di Indonesia. Proporsi terjadinya penularan HIV/AIDS dari ibu ke bayi periode transmisi kehamilan 5-10\%, persalinan $10-20 \%$ dan menyusui $10-15 \%$ perlu di antisipasi dini. Upaya untuk menurunkan angka kematian ibu dan bayi salah satunya melalui program pelayanan antenatal care terpadu. Pelayanan antenatal care (ANC) terpadu adalah pelayanan antenatal berkualitas yang diberikan kepada semua ibu hamil secara komprehensif dan terpadu, mencakup upaya promotif, preventif, sekaligus kuratif dan rehabilitatif, yang meliputi pelayanan Kesehatan Ibu dan Anak (KIA), gizi, pengendalian penyakit menular (imunisasi, Human Immunodeficiency Virus (HIV) / Acquired Immunodeficiency Syndrom (AIDS), tuberkulosis (TB), malaria, penyakit menular seksual) dengan tujuan untuk memenuhi hak setiap ibu hamil memperoleh pelayanan antenatal yang berkualitas sehingga mampu menjalani kehamilan dengan sehat, bersalin dengan selamat dan melahirkan bayi yang sehat dan berkualitas. Hasil Clinical review menunujukkan bahwa penggunaan obat
Antiretroviral (ARV) dapat secara efektif mencegah penularan HIV dari ibu ke bayi (Nightingale et al, 2006; Montolalu, 2014). Kasus AIDS yang terjadi pada anak usia dibawah 5 tahun telah mencapai 141 anak (1,4\%). Jumlah kasus AIDS bila dikelompokkan berdasarkan faktor risiko maka proporsi terbesar disebabkan karena Injection Drug User (IDU) sebanyak 49,5\% dan kasus AIDS yang terjadi karena transmisi perinatal sebanyak 166 kasus $(1,6 \%)$.

\section{METODE}

Metode yang digunakan dalam penelitian ini adalah analitik observational dengan rancangan crosssectional, karena dalam penelitian ini peneliti ingin mencari hubungan antar variabel untuk menerangkan kejadian atau fenomena yang diamati. Subyek penelitian adalah ibu hamil yang ada di wilayah Puskesmas Sleman. Sampel penelitian 104 orang dengan teknik pengambilan sampel purposive sampling. Alat penelitian ini kuesioner. Analisis data adalah univariate dan bivariate. 


\section{HASIL DAN PEMBAHASAN}

Lokasi penelitian ini dilakukan di Puskesmas Sleman Jl. Letkol Subadri, Triharjo, Kecamatan Sleman, Kabupaten Sleman, Daerah Istimewa Yogyakarta. Puskesmas Sleman merupakan salah satu Unit Pelaksanaan Teknis Dinas (UPTD) yang berada dibawah dan bertanggung jawab kepada Dinas Kesehatan Kabupaten Sleman.

1) Analisis Univariat

a) Karakteristik Responden

Karakteristik responden dalam penelitian ini berdasarkan :

1. Usia responden

Usia responden dikelompokan menjadi dua kelompok yaitu usia yang tidak berisiko untuk hamil dengan usia 20 sampai dengan 35 tahun dan usia yang berisiko untuk hamil dengan usia lebih dari 35 tahun.

2. Umur kehamilan

Umur kemahilan dikelompokan menjadi dua yaitu usia kehamilan trimester II dan usia kehamilan trimester III
3. Frekuensi pemeriksaan kehamilan Frekuensi pemeriksaan kehamilan dikelompokan menjadi dua yaitu frekuensi pemeriksaan lebih dari 4 (empat) kali dan frekuensi pemeriksaan kurang dari 4 (empat) kali. Frekuensi pemeriksaan ini dapat diketahui melalui buku Kesehatan Ibu dan Anak (KIA) yang di miliki oleh ibu hamil dan juga data kohort PWS-KIA yang dimiliki oleh petugas Puskesmas.

\section{Tempat ANC}

Tempat ANC dikelompokan menjadi dua yaitu Faskes diantaranya adalah Puskesmas, RB, Bidan Praktek, RS dan non faskes.

Distribusi frekuensi karakteristik responden dalam penelitian ini adalah sebagai berikut: 
Tabel 1.Distribusi Frekuensi Karakteristik Ibu hamil di Puskesmas Sleman Tahun 2018

\begin{tabular}{|c|c|c|}
\hline \multirow{2}{*}{\multicolumn{3}{|c|}{$\begin{array}{l}\text { Karakeristik } \\
\text { Usia }\end{array}$}} \\
\hline & & \\
\hline a. 20-35 tahun & 89 & 85,6 \\
\hline b. $>35$ tahun & 15 & 14,4 \\
\hline \multicolumn{3}{|l|}{ Umur kehamilan } \\
\hline a. Trimester II & 0 & 0,0 \\
\hline b. Trimester III & 104 & 100,0 \\
\hline \multicolumn{3}{|l|}{ Frekuensi pemeriksaan $>4 \mathrm{x}$} \\
\hline a. Tidak & 7 & 6,7 \\
\hline b. Ya & 97 & 93,3 \\
\hline \multicolumn{3}{|l|}{ Tempat ANC } \\
\hline a. Faskes & 104 & 100,0 \\
\hline b. Non faskes & 0 & 0,0 \\
\hline Jumlah & 104 & 100,0 \\
\hline
\end{tabular}

Tabel 1 menunjukkan bahwa karakteristik responden sebagian besar ibu berusia 20-35 tahun sebanyak 89 orang $(85,6 \%)$. Umur kehamilan ibu semuanya pada trimester III sebanyak 104 orang $(100,0 \%)$, frekuensi pemeriksaan kehamilan $>4$ kali sebanyak 97 orang $(93,3 \%)$ dan tempat ANC di faskes sebanyak 104 orang (100,0\%) diantaranya adalah ANC di Puskesmas sebanyak 58 orang $(55,76 \%)$, ANC di RB sebanyak 12 orang (11,53\%), di Bidan sebanyak 24 orang (23,07\%), di Rumah sakit sebanyak 10 orang $(9,61 \%)$.

b) Deskripsi Pelayanan Antenatal Care (ANC) Terpadu dan Pemeriksaan PPIA

1. Deskripsi Pelayanan Antenatal Care (ANC) Terpadu dibagi menjadi dua kelompok yaitu pelayanan ANC yang tidak baik dan Pelayanan ANC yang baik. Pelayanan ANC yang tidak baik adalah pelayanan ANC yang di lakukan di faskes tapi tidak memenuhi standar 10T (Timbang berat badan dan ukut tinggi badan, Ukur tekanan darah, Nilai status gizi/ukur lingkar lengan atas (LiLA), Ukur tinggi fundus uteri, Tentukan presentasi janin dan denyut jantung janin (DJJ), Skrining status imunisasi TT, Tablet tambah darah, Pemeriksaan laboratorium (Hb, Protein, sifilis, HIV dan bakteri tahan asam (BTA), Tatalaksana/penanganan kasus, Temu wicara/konseling), hal ini didapatkan pada ibu hamil yang bekerja sehingga tidak sempat melakukan pemeriksaan 10T yaitu pada indikator temuwicara dan tes laboratorium. Sedangkan pelayanan ANC yang baik 
adalah pelayanan ANC yang dilakukan di faskes dan memenuhi standar 10T.

2. Deskripsi Pemeriksaan Pencegahan Penularan dari Ibu ke Anak di Wilayah Puskesmas Sleman dikelompokkan menjadi dua yaitu Ibu hamil yang tidak melakukan pemeriksaan PPIA dan Ibu hamil yang melakukan pemeriksaan PPIA. Deskripsi data penelitian jawaban responden mengenai pelayanan pelayanan Antenatal Care (ANC) Terpadu dan Pemeriksaan PPIA di Puskesmas Sleman disajikan pada tabel berikut :

Tabel 2.Distribusi Frekuensi Pelayanan Antenatal Care (ANC) Terpadu dan Pemeriksaan PPIA di Wilayah Puskesmas Sleman

\begin{tabular}{|c|c|c|c|}
\hline & Variabel & $\mathrm{F}$ & $\%$ \\
\hline \multicolumn{4}{|l|}{ Pelayanan ANC } \\
\hline a. Tidak Baik & 14 & & 13,5 \\
\hline b. Baik & 90 & & 86,5 \\
\hline \multicolumn{4}{|l|}{ Pemeriksaan PPIA } \\
\hline a. Tidak Melakukan & 5 & & 4,8 \\
\hline \multirow[t]{2}{*}{ b. Melakukan } & 99 & & 95,2 \\
\hline & Jumlah 104 & & 100,0 \\
\hline
\end{tabular}

Tabel 2 menunjukkan status pelayanan kategori tidak melakukan.

ANC ibu hamil dengan kategori baik 2) Analisis Bivariat sebanyak 90 orang $(86,5 \%)$ dan 14 Hasil uji Chi-Square pelayanan responden $(13,5 \%)$ dengan kategori Antenatal Care (ANC) terpadu dengan tidak baik. Pemeriksaan PPIA sebanyak pemeriksaan Pencegahan Penularan dari 99 responden $(95,2 \%)$ kategori Ibu ke Anak (PPIA) pada ibu hamil melakukan dan 5 responden $(4,8 \%)$ dilihat pada tabel di bawah ini: 
Tabel 3. Uji Chi-Square Pelayanan Antenatal Care (ANC) terpadu dengan pemeriksaan Pencegahan Penularan dari Ibu ke Anak (PPIA) pada Ibu Hamil

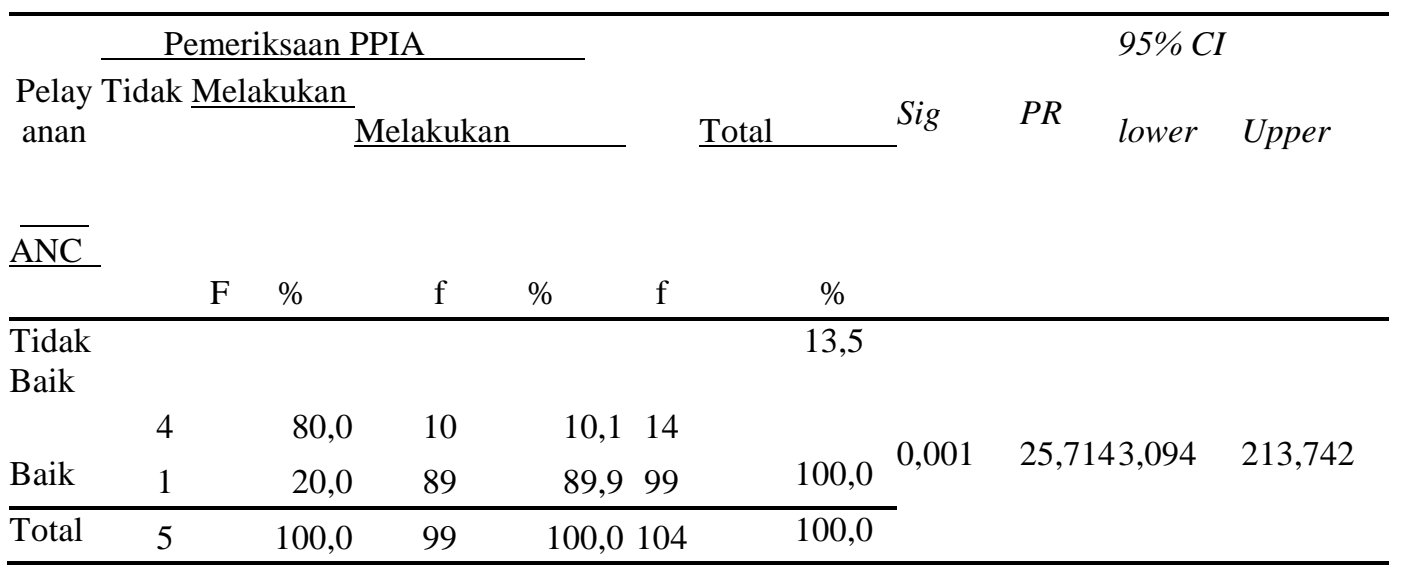

Tabel 3. menunjukkan nilai signifikan $0,001(\mathrm{p}<0,05)$, maka dapat diketahui terdapat hubungan antara pelayanan Antenatal Care (ANC) terpadu dengan pemeriksaan Pencegahan Penularan dari Ibu ke Anak (PPIA) pada Ibu Hamil di Wilayah Puskesmas Sleman 2018, nilai Prevalensi Risk 25,714 (>1) dan nilai $C I$ antara 3,094 dengan 213,742 sehingga tidak melewati angka satu, artinya variabel tersebut merupakan faktor risiko. Dalam penelitian ini juga didapatkan batas atas dan bawah pada lower dan Upper 95\% CI terlalu jauh, hal ini disebabkan karena tabel pada jawaban kuesioner tempat pelayanan ANC $100 \%$ dilayani di faskes.

Penelitian ini dilakukan untuk mengetahui hubungan antara pelayanan Antenatal Care (ANC) terpadu dengan pemeriksaan Pencegahan Penularan dari Ibu ke Anak (PPIA) pada Ibu Hamil di Puskesmas Sleman 2018.

1. Pelayanan Antenatal Care (ANC) terpadu pada Ibu Hamil di Puskesmas Sleman 2018.

Hasil penelitian menunjukkan bahwa sebanyak 90 orang $(86,5 \%)$ Ibu Hamil menilai kualitas pelayanan Antenatal Care (ANC) terpadu di Puskesmas Sleman dalam kategori baik. Penerapan standar pelayanan yang baik dalam pelayanan Antenatal Care (ANC) terpadu di Puskesmas Sleman sangat berguna untuk melindungi masyarakat karena proses kegiatan yang dilakukan mempunyai dasar yang jelas.

Kondisi sebenarnya tentang Pelayanan Antenatal Care (ANC) terpadu pada Ibu hamil tahun 2018 yang sudah 
dilaksanakan di Puskesmas Sleman yaitu sejak di keluarkanya regulasi dari Dinas Kesehatan dalam bentuk surat edaran No 444/9332 tahun 2017 tentang Pelayanan ANC Terpadu (10T) pada Ibu hamil, Puskesmas Sleman sudah memberikan pelayanan ANC terpadu kepada seluruh ibu hamil yang berada di wilayah Puskesmas Sleman. Adanya surat edaran ini juga meningkatkan kerja sama antara Puskesmas dengan Fasilitas-fasilitas kesehatan swasta yang memberikan pelayanan Ibu hamil sehingga pelayanan ANC terpadu terlaksana dengan baik.

Hasil penelitian tersebut sesuai dengan penelitian yang menunjukkan bahwa pelaksanaan standar pelayanan ANC di puskesmas Bahu menurut kategori menunjukkan bahwa sebagian besar pelayanan ANC di Puskesmas bahu sesuai dengan standar pelayanan kebidanan dibandingkan pelayanan yang tidak sesuai dengan standar pelayanan kebidanan ${ }^{3}$. Berdasarkan data tersebut, diketahui bahwa pelayanan ANC sudah baik $(82,6 \%)$ dari responden. Pelaksanaan standar ANC yang merupakan ukuran kualitas pelayanan kepada ibu hamil adalah prediktor yang bermakna terhadap pemanfaatan perawatan.
Pelayanan antenatal adalah pelayanan kesehatan oleh tenaga profesional untuk ibu selama masa kehamilan, yang dilaksanakan sesuai dengan standar pelayanan antenatal yang ditetapkan ${ }^{4}$. Kualitas pelayanan sangat erat dengan hubungannya pada penerapan. Pelayanan yang diberikan harus mengacu pada standar yang telah ditetapkan yaitu standar pelayanan kebidanan.

Tujuan perawatan ANC di Puskesmas Sleman dengan pendekatan standar adalah menghasilkan ibu dan bayi yang sehat pada akhir kehamilan dengan 1) mencegah dan menangani masalah yang berkaitan dengan kehamilan atau intercurrent morbidity, 1) hipertensi pada masa kehamilan, anemia, malaria, tetanus, penyakit menular seksual dan 2) mendeteksi ibu yang memiliki risiko tinggi mengalami komplikasi ketika melahirkan (Montolalu, A., Kusmiyati, Manueke, I. 2014). Perawatan ANC dilakukan untuk memenuhi hak setiap ibu hamil melalui pelayanan antenatal yang berkualitas sehingga mampu menjalani kehamilan dengan sehat, bersalin dengan selamat dan melahirkan bayi yang sehat dan berkualitas. Dalam pelayanan antenatal 
terpadu, tenaga kesehatan harus dapat memastikan bahwa kehamilan berlangsung normal, mampu mendeteksi dini masalah dan penyakit yang dialami ibu hamil, melakukan intervensi secara adekuat sehingga ibu hamil siap untuk menjalani persalinan normal (Kemenkes RI, 2010).

Berdasarkan hasil penelitian sebelumnya dan teori dapat disimpulkan bahwa pelayanan Antenatal Care (ANC) ibu hamil di Puskesmas Sleman dalam kategori baik. Penerapan standar pelayanan yang baik dalam pelayanan Antenatal Care (ANC) terpadu di Puskesmas Sleman sangat berguna untuk melindungi masyarakat karena proses kegiatan yang dilakukan mempunyai dasar yang jelas dan mampu mendeteksi dini masalah dan penyakit yang dialami ibu hamil.

2. Pemeriksaan Pencegahan Penularan dari Ibu ke Anak (PPIA) pada Ibu Hamil di Puskesmas Sleman 2018.

Hasil penelitian menunjukkan bahwa sebanyak 99 orang $(95,2 \%)$ Ibu Hamil melakukan Pemeriksaan Pencegahan Penularan dari Ibu ke Anak (PPIA) di Puskesmas Sleman 2018. Hasil dari penelitian ini mendukung komponen kegiatan PPIA yang ada pada prong 3 yaitu pencegahan penularan HIV dari ibu hamil dengan HIV ke bayi yang dikandungnya.

Kondisi sebenarnya tentang Pemeriksaan Pencegahan Penularan dari Ibu ke Anak (PPIA) pada Ibu Hamil di Puskesmas Sleman tahun 2018, yaitu di keluarkanya regulasi dari Gubernur Daerah Istimewa Yogyakarta surat edaran No 18/SE/XII/ 2017 tentang Pelaksanaan Eliminasi Penularan HIV, Sifilis dan Hepatitis B dari Ibu ke Anak di Indonesia, Puskesmas Sleman sudah memberikan pelayanan Pemeriksaan Pencegahan Penularan dari Ibu ke Anak (PPIA) pada Ibu di wilayah Puskesmas Sleman. Adanya surat edaran ini juga meningkatkan kerja sama antara Puskesmas dengan Fasilitas-fasilitas kesehatan swasta.

Hasil tersebut sesuai dengan penelitian yang menunjukkan bahwa sebagian besar responden melakukan pemeriksaan PITC yaitu sebanyak 71 responden (98,6\%) (Djoko, et all, 2000). Penelitian lain yang sesuai dengan penelitian ini menyatakan bahwa ibu memiliki kesiapan pada kategori siap untuk melakukan tes HIV/AIDS yaitu sebanyak 65 responden $(55,6 \%)$. Hasil penelitian tersebut menyatakan bahwa 
ibu yang memiliki kesiapan dalam melakukan tes HIV/AIDS merupakan ibu yang memiliki pendidikan menengah dan tinggi sehingga mempengaruhi pengetahuan responden mengenai HIV/AIDS itu sendiri, hal tersebut juga dilihat berdasarkan hasil observasi yang didapatkan hasil bahwa responden yang siap melakukan tes HIV/ AIDS mereka cukup memiliki wawasan mengenai penyakit HIV/AIDS (Nurmasari, A., Fatimah, Suci, F, H., 2015). Pencegahan Penularan Ibu ke Anak (PPIA) merupakan bagian dari rangkaian upaya pengendalian HIV dan AIDS. Tujuan utamanya adalah agar bayi yang dilahirkan dari ibu dengan HIV terbebaskan dari HIV, serta ibu dan bayi tetap hidup dan sehat. Kebijakan umum PPIA sejalan dengan kebijakan program nasional pengendalian HIVAIDS dan IMS lainnya, serta kebijakan program KIA (Kementrian Kesehatan RI. 2010b).

Kesediaan Ibu dalam melakukan Pemeriksaan Pencegahan Penularan dari Ibu ke Anak (PPIA) pada Ibu Hamil di Puskesmas Sleman secara sukarela merupakan salah satu bentuk partisipasi dan ibu memiliki pengetahuan tentang pencegahan HIV/AIDS serta perilaku yang baik. Dengan adanya pengetahuan yang cukup baik sebenarnya ibu hamil akan merasa lebih yakin dalam mengambil keputusan tes HIV/AIDS secara sukarela.

Pengetahuan yang dimiliki akan menjadi dasar dari segala tindakan yang dilakukan. Sedangkan ibu hamil yang tidak bersedia mengikuti pelayanan PPIA dan VCT sebagian besar dikarenakan stigma negative yang ada didalam masyarakat. Dengan stigma tersebut, masyarakat akan enggan untuk melakukan pemeriksaan dikarenakan mal dan takut jika diketahui oleh orang lain (Ni'amah dan Irnawati. 2017). Berdasarkan hasil penelitian sebelumnyadan teori dapat disimpulkan bahwa sebanyak 99 orang $(95,2 \%)$ Ibu Hamil melakukan Pemeriksaan Pencegahan Penularan dari Ibu ke Anak (PPIA) di Puskesmas Sleman 2018. Kesediaan Ibu dalam melakukan Pemeriksaan Pencegahan Penularan dari Ibu ke Anak (PPIA) pada Ibu Hamil di Puskesmas Sleman secara sukarela merupakan salah satu bentuk partisipasi dan ibu memiliki pengetahuan tentang pencegahan HIV/AIDS serta perilaku yang baik.

3. Hubungan antara pelayanan Antenatal 
Care (ANC) terpadu dengan pemeriksaan Pencegahan Penularan dari Ibu ke Anak (PPIA) pada Ibu Hamil di Puskesmas Sleman.

Berdasarkan hasil penelitian menunjukkan bahwa nilai signifikan 0,001 ( $\mathrm{p}<0,05)$, maka dapat diketahui terdapat hubungan antara pelayanan Antenatal Care (ANC) terpadu dengan pemeriksaan Pencegahan Penularan dari Ibu ke Anak (PPIA) pada Ibu Hamil di Wilayah Puskesmas Sleman 2018, nilai Prevalensi Risk 25,714 (>1) dan nilai $C I$ antara 3,094 dengan 213,742 sehingga tidak melewati angka satu, artinya variabel tersebut merupakan faktor risiko. Dalam penelitian ini juga didapatkan batas atas dan bawah pada lower dan Upper 95\% CI terlalu jauh, hal ini disebabkan karena tabel pada jawaban kuesioner tempat pelayanan ANC 100\% dilayani di faskes.

Kondisi sebenarnya tentang pelayanan Antenatal Care (ANC) terpadu dengan Pemeriksaan Pencegahan Penularan dari Ibu ke Anak (PPIA) pada Ibu Hamil di Puskesmas Sleman 2018 mempunyai hubungan yang sangat erat, karena melalui pelayanan ANC terpadu ini Ibu hamil diberikan edukasi lewat temu wicara/konseling tentang penyakit HIV, faktor penyebab dan cara pencegahannya, sehingga Ibu hamil terdorong untuk melaksanakan Pemeriksaan Pencegahan Penularan dari Ibu ke Anak (PPIA) .

Penelitian tersebut sesuai dengan penelitian yang dilakukan di Kenya yang menyatakan terdapat hubungan antara pelayanan ANC terpadu terhadap pencegahan HIV. Integrasi penuh perawatan HIV ke klinik antenatal dapat secara signifikan meningkatkan kepuasan keseluruhan dengan perawatan untuk ibu dalam pencegahan HIV (Baotran Et All. 2011).

Hasil penelitian lain yang sesuai dengan penelitian ini menunjukkan bahwa ada hubungan signifikan pelayanan berdasarkan jumlah kunjungan ANC $(\mathrm{p}=0,000)$ dengan keikutsertaan ibu hamil dalam tes HIV, dimana semakin banyak jumlah kunjungan pemeriksaan kehamilan maka ibu hamil cenderung untuk mengikuti tes HIV salah satunya pemeriksaan Pencegahan Penularan dari Ibu ke Anak (PPIA), namun bisa juga keikutsertaan dalam pemeriksaan Pencegahan Penularan dari Ibu ke Anak (PPIA) tidak hanya dipengaruhi oleh faktor pelayanan 
pemeriksaan kehamilan namun juga faktor-faktor yang lain seperti dukungan petugas kesehatan (Sari, Sulistyono Dan Notobroto. 2016). Legiati., et al (2012) yang mengatakan bahwa pengetahuan ibu hamil dipengaruhi oleh dukungan atau peran petugas kesehatan. Ibu hamil yang memiliki pengetahuan baik lebih banyak mengikuti tes HIV dibandingkan dengan ibu hamil yang memiliki pengetahuan yang kurang (Ariningtyas, N. 2017). Pelayanan pemeriksaan kehamilan atau pelayanan Antenatal Care (ANC) dan dukungan petugas kesehatan sangat berpengaruh dalam mempengaruhi Ibu hamil di Puskesmas Sleman dalam pemeriksaan Pencegahan Penularan dari Ibu ke Anak (PPIA), sebab petugas kesehatan sering berinteraksi sehingga pemahaman tentang kondisi fisik maupun psikis lebih baik, dengan sering berinteraksi dan memberikan pelayanan yang baik akan sangat berpengaruh rasa percaya dan menerima kehadiran petugas bagi dirnya, serta edukasi dan konseling yang diberikan petugas sangat besar artinya terhadap Ibu hamil yang memanfaatkan pelayanan PPIA.

Pemberian pelayanan kesehatan yang baik merupakan langkah yang dilakukan secara berkesinambungan terhadap diagnose potensi yang mungkin dialami ibu hamil, yaitu terjadinya masalah potensial pada kesehatan ibu. Tidak adanya resiko penularan penyakit terhadap anak dapat dilakukan dengan upaya pencegahan. Islam sangat memperhatikan dunia kesehatan dan keperawatan guna menolong orang yang sakit dan meningkatkan kesehatan.

Layanan PPIA mempunyai sasaran, tujuan dan pendekatan yang banyak persamaannya dengan upaya pencegahan sifilis kongenital, karena itu kedua upaya ini di integrasikan ${ }^{7}$. Keberhasilan upaya pencegahan penularan HIV dari Ibu ke bayi sangat bergantung pada berbagai pihak, sehingga tidak hanya berpengaruh pada peran aktif petugas kesehatan dan pelayanan dalam memberikan edukasi dan informasi tentang HIV kepada Ibu dan keluarganya, namun dapat dilakukan dengan berbagai upaya.

Upaya dalam keberhasilan pencegahan penularan HIV dapat dilakukan dengan peningkatan peran Bidan maupun Dokter Praktek Swasta untuk melaksanakan program PPIA sampai bisa menjangkau semua wilayah khususnya wilayah yang jauh dari pusat pelayanan kesehatan. Hal tersebut 
dilakukan dalam rangka meningkatkan pengetahuan dan pemahaman masyarakat, khususnya ibu hamil termasuk di dalamnya yaitu pada keluarga terkait informasi tentang HIV AIDS dan pentingnya tes HIV (Kementrian Kesehatan RI, 2010).

Berdasarkan hasil penelitian sebelumnya dan teori dapat disimpulkan bahwa ada hubungan antara pelayanan Antenatal Care $(A N C)$ terpadu dengan pemeriksaan Pencegahan Penularan dari Ibu ke Anak (PPIA) pada Ibu Hamil di Puskesmas Sleman. Pelayanan pemeriksaan kehamilan atau pelayanan Antenatal Care (ANC) dan dukungan petugas kesehatan sangat berpengaruh dalam mempengaruhi Ibu hamil di Puskesmas Sleman dalam pemeriksaan Pencegahan Penularan dari Ibu ke Anak (PPIA). Hal ini sejalan dengan hasil penelitian Setiyawati \& Meilani (2014) yang menunjukkan bahwa inisiasi dari pemberi layanan kesehatan atau PITC (Provider Initiated Testing and Counselling) di puskesmas secara statistik menunjukkan adanya hubungan dengan perilaku ibu hamil dalam tes HIV. Inisiasi dari pemberi layanan kesehatan untuk melakukan tes HIV berpeluang untuk melakukan tes HIV sebesar 21,6 kali lebih besar dibandingkan dengan ibu hamil yang tidak mendapatkan inisiasi dari pemberi layanan kesehatan (Legiati, T., Shaluhiyah, Z., Antono Suryoputro, A., 2012).

Hal yang sama dikemukakan oleh peneliti lainnya yang mengatakan bahwa dengan memberi tawaran kepada ibu untuk konseling dan tes HIV pada saat ibu melakukan ANC, keikutsertaan ibu untuk konseling dan tes 1,3 kali lebih tinggi $(95 \% \quad \mathrm{CI}=17,3-22,0)$ dibanding dengan ibu tidak ditawarkan konseling dan tes HIV (Setiyawati, N \& Meilani, N, 2014).

\section{SIMPULAN DAN SARAN}

Berdasarkan hasil penelitian dan pembahasan, maka dapat ditarik kesimpulan pelayanan Antenatal Care (ANC) ibu hamil di Puskesmas Sleman dalam kategori baik. Pemeriksaan Pencegahan Penularan dari Ibu ke Anak (PPIA) pada ibu hamil di Puskesmas Sleman dalam kategori melakukan pemeriksaan. Ada hubungan antara pelayanan Antenatal Care (ANC) terpadu dengan pemeriksaan Pencegahan Penularan dari Ibu ke Anak (PPIA) pada Ibu Hamil di Puskesmas Sleman. 
Hasil penelitian ini diharapkan dapat menambah informasi kepada masyarakat tentang manfaat antenatal care terpadu dan manfaat pemeriksaan Pencegahan Penularan dari Ibu ke Anak (PPIA) serta memberikan tambahan informasi bagi petugas kesehatan tentang pentingnya program ANC Terpadu dan pemeriksaan PPIA dalam membantu menurunkan AKI dan AKB akibat penyakit HIV.

\section{DAFTAR PUSTAKA}

Dinkes DIY. 2017. Buku Profil Kesehatan Daerah Istimewa Yogyakarta Tahun 2017, Yogyakarta. Dinkes DIY.

Kementrian Kesehatan RI. 2010a. Pedoman Pemantauan Wilayah Setempat Kesehatan Ibu dan Anak (PWS-KIA), Jakarta. Direktorat Jendral Bina Kesehatan Ibu dan Anak, Kemenkes RI.

Andriani S. 2009. Hubungan Kualitas Pelayanan Kesehatan Dengan Kepuasan Pasien Rawat Inap Di Badan Pelayanan Kesehatan Rumah Sakit Umum Daerah Kabupaten Magelang. Jurnal Kesehatan. ISSN 1979 - 7621. Vol. 2. No. 1. Juni 2009 Hal $71-79$.

Nightingale S, Dabis F. Evidence behind the WHO Guidelines: Hospital Care For Children: What Antiretroviral Agents and Regimens are Effective in the Prevention of Mother-to-child Transmission? $J \quad$ Pediatr. (2006);52(4):235-38.

Montolalu, A., Kusmiyati, Manueke, I. 2014. Hubungan Pelaksanaan Standar Pelayanan Antenatal dengan Keikutsertaab Ibu Hamil untuk Konseling Tes HIV. Jurnal Kesehatan Ibu Hamil. Manado. Poltekes Kemenkes Manado. Vol 4, No.1.
Joo E, Carmack A., Gracia-Bunuel E, Nelly C L. Implementasi of Guidelines for HIV Counseling and Voluntary Testing of Pregnant Women Am J Public Health (2000);90 (2):273- 76.

Djoko, W. 2008. Manajemen Kesehatan Ibu dan Anak-Prinsip dan Strategi Pendekatan Komunitas, Surabaya. Erlangga.

Nurmasari, A., Fatimah, Suci, F, H., 2015. Tingkat Pengetahuan Ibu Hamil Tentang HIV/AIDS dengan Perilaku Pemeriksaan PITC (Provider Intiated Testing and Counseling) di Puskesmas Sleman Yogyakarta, Jurnal Kesehatan Masyarakat. Yogyakarta, Alma Ata Yogyakarta. Vol.5 No.2.

Kementrian Kesehatan RI. 2010b. Pedoman Penerapan Tes dan Konseling HIV Terintegrasi di Sarana Kesehatan/PITC. Jakarta. Direktorat Jendral Pengendalian Penyakit dan Penyehatan Lingkungan, Kemenkes RI.

Ni'amah dan Irnawati. 2017. Studi Deskriptif Pengetahuan Ibu Hamil tentang HIV/AIDS dan VCT dengan Kesediaan Mengikuti VCT di Kabupaten Pati. The 6th University Research Colloquium 2017. Universitas Muhammadiyah Magelang.

Baotran Et All. 2011. Patient Satisfaction With Integrated Hiv And Antenatal Care Services In Rural Kenya. Journal Aids Care Psychological And Socio-Medical Aspects Of AIDS/HIV , Volume 24, 2012 - Issue 11.

Sari, Sulistyono Dan Notobroto. Hubungan Jumlah Kunjungan Anc Dan Stigmatisasi Dengan Keikutsertaan Ibu Hamil Dalam Tes Hiv Setelah Konseling Oleh Petugas Kesehatan (Di Wilayah Kerja Puskesmas Turi Lamongan, The Indonesian Journal of Public Health, Vol. 11 No. 1, Desember 2016: 89-98.

Ariningtyas, N. 2017. Kendala Program PPIA pada Antenatal Care. Jurnal Kesehatan Samudra Ilmu, 8. 
Kementrian Kesehatan RI. 2010. Modul Penerapan Tes dan Konseling HIV Terintegrasi di Sarana Kesehatan/PITC. Jakarta. Direktorat Jendral Pengendalian Penyakit dan Penyehatan Lingkungan, Kemenkes RI.

Legiati, T., Shaluhiyah, Z., Antono Suryoputro, A. (2012). Perilaku Ibu Hamil untuk Tes
HIV di Kelurahan Bandarharjo dan Tanjung Mas Kota Semarang. Jurnal Promosi Kesehatan Indonesia, 7 (2).

Setiyawati, N \& Meilani, N. (2014). Determinan Perilaku Tes HIV pada Ibu Hamil. Jurnal Kesehatan Masyarakat Nasional, 9 (3). 